\title{
Clinical Procedures for the Prevention of Preeclampsia in Pregnant Women: A Systematic Review
}

\section{Procedimentos clínicos para a prevenção de pré-eclâmpsia em gestantes: Uma revisão sistemática}

\author{
Nádya Santos Moura1( ${ }^{10}$ Maria Luziene Sousa Gomes ${ }^{1(1)}$ Ivana Rios Rodrigues ${ }^{10}$

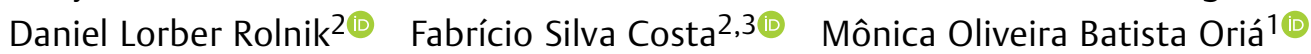
${ }^{1}$ Department of Nursing, Faculdade de Farmácia, Odontologia e Enfermagem, Universidade Federal do Ceará, Fortaleza, CE, Brazil
${ }^{2}$ Department of Obstetrics and Gynecology, Monash University, Melbourne, Victoria, Australia
${ }^{3}$ Departament of Gynecology and Obstetrics, Faculdade de Medicina de Ribeirão Preto, Universidade de São Paulo, Ribeirão Preto, São Paulo, Brazil,

Address for correspondence Mônica Oliveira Batista Oriá, PhD, Rua, Rua Alexandre Baraúna 1.115, Rodolfo Teófilo, Fortaleza, CE, 60430-

Rev Bras Ginecol Obstet 2020;42(10):659-668.

\begin{abstract}
Objective To identify the most effective procedures recommended for the prevention of preeclampsia.

Data Sources A systematic review was performed in the following databases: Pubmed/MEDLINE, CINAHL, Web of Science, Cochrane and LILACS via the Virtual Health Library (VHL). A manual search was also performed to find additional references. The risk of bias, the quality of the evidence, and the classification of the strength of the recommendations were evaluated using the Grading of Recommendations, Assessment, Development and Evaluations (GRADE) approach.

Selection of Studies In the initial search in the databases, the total number of articles retrieved was 351, and 2 were retrieved through the manual search; after duplicate articles were removed, 333 citations remained. After a thorough review of the titles and abstracts, 315 references were excluded. Accordingly, 18 articles were maintained for selection of the complete text (phase 2). This process led to the exclusion of 6 studies. In total, 12 articles were selected for data extraction and qualitative synthesis. Data Collection The articles selected for the study were analyzed, and we inserted the synthesis of the evidence in the online software GRADEpro Guideline Development

Keywords

- pregnant women

- preeclampsia

- prevention and control

- maternal health

- pregnancy complications Tool (GDT) (McMaster University and Evidence Prime Inc. All right reserved. McMaster University, Hamilton, Ontário, Canada); thus, it was possible to develop a table of evidence, with the quality of the evidence and the classification of the strength of the recommendations.

Data Synthesis In total, seven studies recommended the individual use of aspirin, or aspirin combined with calcium, heparin or dipyridamole. The use of calcium alone or in combination with phytonutrients was also highlighted. All of the studies were with women at a high risk of developing preeclampsia.
\end{abstract}

received

May 3, 2020

accepted

June 3, 2020
DOI https://doi.org/

10.1055/s-0040-1714135. ISSN 0100-7203.
Copyright $(2020$ by Thieme Revinter

Publicações Ltda, Rio de Janeiro, Brazil
License terms

(c) (1) 


\section{Resumo}

\author{
Palavras-chave \\ - gestante \\ - pré-eclâmpsia \\ - prevenção e \\ controle \\ - saúde materna \\ - complicações na \\ gravidez
}

Conclusion According to the studies evaluated, the administration of aspirin is still the best procedure to be used in the clinical practice to prevent preeclampsia.

Objetivo Identificar quais são as condutas recomendadas para a prevenção de préeclâmpsia em gestantes.

Fontes de Dados Foi feita uma revisão sistemática da literatura, e foram desenvolvidas estratégias detalhadas de busca individual nas bases de dados PubMed/MEDLINE, CINAHL, Web of Science, Cochrane e LILACS pela Biblioteca Virtual em Saúde (BVS). Uma pesquisa manual também foi realizada para encontrar referências adicionais. $O$ risco de viés, a qualidade da evidência, e a classificação da força das recomendações foram avaliadas usando a abordagem Classificação de Recomendações, Avaliação, Desenvolvimento e Análises (Gradings of Recommendations, Assessment, Development and Evaluations, GRADE).

Seleção dos Estudos No total, foram encontrados 351 artigos na busca inicial nas bases de dados consultadas e 2 na busca manual; após exclusões por duplicidade, 333 artigos permaneceram. Após a leitura de títulos e resumos, 315 referências foram excluídas. Portanto, 18 artigos foram mantidos para a seleção do texto completo (fase 2); esse processo levou à exclusão de 6 artigos. Após as exclusões por incompatibilidade com os critérios de inclusão, 12 artigos compuseram a amostra.

Coleta de Dados Os artigos selecionados para o estudo foram analisados, e a digitação da síntese das evidências foi realizada no software online GRADEpro Guideline Development Tool (GDT) (McMaster University and Evidence Prime Inc. Todos os direitos reservados. McMaster University, Hamilton, Ontário, Canadá), o que possibilitou a elaboração de uma tabela de evidências, com a qualidade das evidências e a classificação da força das recomendações.

Síntese dos Dados No total, sete estudos recomendaram o uso individual de aspirina, ou aspirina combinada com cálcio, heparina ou dipiridamol. O uso de cálcio isolado ou em combinação com fitonutrientes também foi destacado. Todos os estudos foram realizados com mulheres com alto risco de desenvolver pré-eclâmpsia.

Conclusão De acordo com os estudos avaliados, a administração de aspirina ainda é a melhor conduta a ser utilizada na prática clínica para prevenir a pré-eclâmpsia.

\section{Introduction}

Preeclampsia (PE) is a systemic disease, and much of its etiology is unknown. Evidence suggests that it is characterized by angiogenic imbalance, exaggerated inflammation and endothelial dysfunction, leading to clinical manifestations of pregnancy-specific hypertension, which usually occurs in the second half of pregnancy. ${ }^{1,2}$

It is one of the main causes of maternal and perinatal death, affecting $3 \%$ to $5 \%$ of pregnancies worldwide, and accounting for $25.7 \%$ of all maternal deaths in Latin America and the Caribbean. ${ }^{3,4}$ The risk of these complications is greater when the disease has an early onset (before 34 weeks of gestation), and it is serious, as it causes restricted intrauterine growth (RIG) or fetuses that are small for the gestational age (SGA), severe maternal morbidities, and it also causes women to become more prone to develop cardiovascular risk factors. The costs for each birth with the presence of preeclampsia have been shown to increase by US\$ $6,583 .^{5-8}$
One of the major challenges for modern obstetrics is the early identification of women at a high risk of developing preterm preeclampsia (before 37 weeks of gestation). Thus, the prediction of preeclampsia is paramount in performing appropriate procedures to reduce the prevalence of the disease by modifying antenatal care and pharmacological interventions in a timely manner. ${ }^{9,10}$

Several clinical, biochemical and biophysical tests have been proposed to predict PE; however, none of them have proved to be useful in isolation to classify the preexisting maternal risk for PE with sufficient specificity and sensitivity for clinical use. Ideally, the predictive model should be simple, inexpensive, and easy to apply, so that it can be widely used in the clinical practice. ${ }^{11}$

Researchers developed a predictive model that is able to predict the risk of developing PE in the first trimester ( 11 weeks, 0 day - 13 weeks, 6 days), based on a combination of maternal factors that includes the mean arterial pressure (MAP), the pulsatility index (PI) of the uterine artery, and the serum placental growth factor (PIGF). This model can predict 
$75 \%$ (95\% confidence interval [95\%CI]: $70-80 \%$ ) of preterm preeclampsia and $47 \%$ (95\%CI: $44-51 \%$ ) of term preeclampsia, with a false-positive rate (FPR) of $10 \%$, with these data being superior to the respective values of $49 \%$ and $38 \%$ achieved by screening with maternal factors only. ${ }^{12}$

Accordingly, strategies to reduce the risk of pregnancyrelated hypertension disorders are a global priority, and screening only makes sense if there is an effective intervention available to prevent the disease and control the unfavorable outcomes. ${ }^{13,14}$ Therefore, the present study sought to answer the following question: what are the most up-todate and effective procedures to prevent PE? The aim of the present review was to identify the most effective procedures recommended for the prevention of PE.

\section{Methods}

\section{Type of Study}

A systematic review based on the Preferred Reporting Items for Systematic Reviews and Meta-Analyses (PRISMA) guidelines. ${ }^{15}$

\section{Eligibility Criteria}

The inclusion criteria were 1) randomized controlled trials (RCTs), systematic reviews/meta-analyses, and prospective or retrospective cohort studies 2) that included pregnant women of all ages, with a single pregnancy and without preeclampsia in the current gestation, 3) which reported the outcome of interest (prevention and control of PE). There were no language restrictions. Articles published between the years of 2013 and 2018 were included. Studies were excluded due to the following reasons: they did not cover the topic; and studies that were letters, abstracts of congresses, personal opinions, chapter of books, descriptive studies, case reports, or case series, study protocols and qualitative studies.

\section{Information Sources and Search Strategy}

The studies were identified through a search strategy adapted for each electronic database: PubMed/MEDLINE, CINAHL, Web of Science, Cochrane and LILACS via the Virtual Health Library (VHL). All of the electronic database searches were performed on December 14, 2018. In a complementary way, a manual search was performed on the reference lists of the selected articles, to ensure that any additional references that might not have been retrieved in the electronic search were duly found. To perform the searches in the electronic databases, the following medical subject headings (MESH) were used: pregnant women, preeclampsia, prevention and control; we also used the AND Boolean operator to search for the combination (pregnant women AND preeclampsia AND prevention and control).

\section{Selection of the Studies}

After collecting all of the references, duplicate articles were deleted using a free online bibliographic reference manager (EndNote Web). The selection of the studies was performed in phases. In phase 1, two investigators independently examined the titles and abstracts of potentially relevant studies and selected articles that appeared to meet the inclusion criteria based on their abstracts. In phase 2 , the same reviewers read the full text of all of the independently-selected articles and excluded studies that did not meet the inclusion criteria. Any disagreements, whether in the first or second phases, were solved through discussions between the two investigators. In the event of failure to reach a consensus, a third reviewer was called to make a final decision.

The studies that were excluded and the reasons for exclusion are presented in -Fig. $\mathbf{1}$.

\section{Data Collection Process}

Two investigators independently collected data from the articles, including: study characteristics (references, year of publication, objective), population characteristics (sample size, gestational age), procedure characteristics (study design, follow-up period) and main results.

\section{Summary of the Measures}

The primary outcome of interest in the study was the prevention of PE. In addition, fetal outcomes (preterm delivery, premature rupture of membranes, restricted intrauterine growth, Apgar score, and fetal/neonatal death) were also considered as secondary outcomes.

\section{Risk of Bias in the Studies and Classification of the Strength of the Recommendations}

The quality of the evidence and the classification of the strength of the recommendations were evaluated through the Grading of Recommendations, Assessment, Development and Evaluations (GRADE) approach. ${ }^{16}$ The synthesis of the evidence was digitalized using the online software GRADEpro Guideline Development Tool (GDT) (McMaster University and Evidence Prime Inc. All right reserved. McMaster University, Hamilton, Ontário, Canada), which made it possible for us to develop the evidence table. The criteria for this evaluation were study design, risk of bias, inconsistency, indirect evidence, inaccuracy, possible publication bias, whether the study had a large effect size, the potential confounding factors, and the dose-response gradients of the procedures. With this, the quality of the evidence was characterized as high, moderate, low or very low.

\section{Results}

\section{Selection of the Studies}

In phase 1 of the study selection, 351 citations were identified in the 5 databases consulted. The manual search from the reference lists of the identified studies provided two additional studies. After duplicate articles were removed, 333 citations remained. After a thorough review of the titles and abstracts, 315 references were excluded. Accordingly, 18 articles were maintained for selection of the complete text (phase 2). This process led to the exclusion of six studies (-Fig. 1). In total, 12 articles were selected for data extraction and qualitative synthesis.

\section{Characteristics of the Studies}

Of the twelve studies selected for the present review, three of them used only aspirin, four used aspirin combined with 


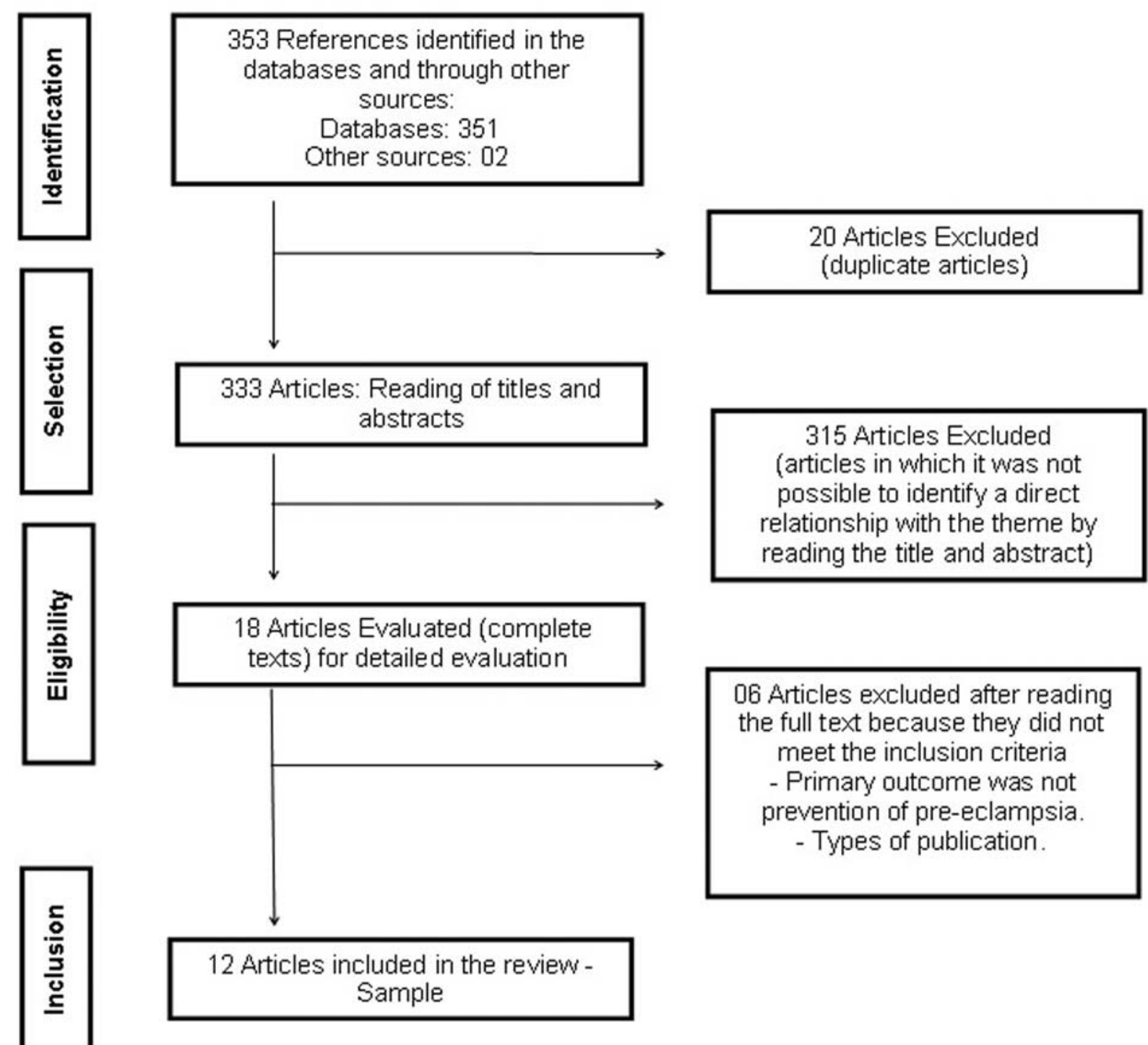

Fig. 1 Flowchart showing the results of the database search, the selection, and the inclusion of original articles in the systematic review.

calcium, heparin or dipyridamole, while the others used only calcium or calcium combined with phytonutrients, L-arginine, heparin or pravastatin as procedures for the prevention of PE. Most studies included women at a high risk of developing PE in their samples; for this, those who had at least one risk factor for the disease were considered at a high risk of developing PE; one of the risk factors analyzed was pregnant women with systemic hypertension before pregnancy, aiming to evaluate superimposed PE.

The descriptive characteristics of the studies are summarized in Chart 1.

\section{Risk of Bias in the Studies and Classification of the Strength of the Recommendations}

The quality of the evidence of the results evaluated through the GRADE system was classified as high certainty, moderate certainty, low certainty and very low certainty (Chart 2).
Most of the studies classified as high-certainty were those that used the administration of aspirin individually as the procedure. The other high-certainty studies used L-arginine, phytonutrients and aspirin with calcium, and they demonstrate that further studies are unlikely to change the confidence in the estimate of the effect of these findings, which allows us to have confidence in these results. Among the high-certainty studies, the use of phytonutrients was not statistically significant in the reduction of the risk of developing PE, a fact that discourages their isolated use as a preventive measure.

One study ${ }^{20}$ involving the addition of low-molecularweight heparin (LMWH) or unfractionated heparin to a low dose of aspirin and one ${ }^{21}$ that used a low dose of aspirin (75 mg) were moderately certain, indicating that additional studies should be performed, and are likely to have an impact on the confidence in the estimate of the effect, and may 
Chart 1 Characteristics of the included articles

\begin{tabular}{|c|c|c|c|c|}
\hline Reference & Study Design & Objective & Sample & Procedure \\
\hline $\begin{array}{l}\text { Rolnik et al } \\
(2017)^{5}\end{array}$ & $\begin{array}{l}\text { Randomized } \\
\text { controlled trial }\end{array}$ & $\begin{array}{l}\text { To evaluate whether low- } \\
\text { dose aspirin during pregnan- } \\
\text { cy reduces the risk of devel- } \\
\text { oping preeclampsia (PE) } \\
\text { before } 37 \text { weeks of pregnan- } \\
\text { cy in high-risk women } \\
\text { according to an individual- } \\
\text { risk calculation algorithm. }\end{array}$ & $\begin{array}{l}798 \text { participants in the aspi- } \\
\text { rin group; } 822 \text { in the placebo } \\
\text { group. }\end{array}$ & $\begin{array}{l}\text { Aspirin at a dose of } 150 \mathrm{mg} \\
\text { per day, administered from } \\
\text { the } 11 \text { th to the } 14 \text { th gesta- } \\
\text { tional weeks until the } 36 \text { th } \\
\text { week. }\end{array}$ \\
\hline
\end{tabular}

Camarena Randomized Pulido et al controlled trial $(2016)^{10}$ et al $(2016)^{3}$ controlled trial

Talari et al Randomized $(2014)^{9} \quad$ controlled trial

Souza et al Randomized $(2014)^{14} \quad$ controlled trial

Parrish et al Randomized $(2013)^{27}$ controlled trial

Roberge et al Systematic review To examine the effect and $(2018)^{25}$ with meta-analysis the dose of aspirin on the prevention of preterm and term $\mathrm{PE}$ in relation to the gestational age at the beginning of the treatment. the incidence of PE.
L-arginine group $(n=50)$ and safety of L-arginine patients.

To evaluate the maternal-fetal safety and pharmacokinetic parameters of pravastatin when used in pregnant women at high risk of developing PE.

To determine whether the treatment with acetylsalicylic acid (ASA) reduces the nant women with abnormal uterine artery flow.

To test the hypothesis that and low-dose aspirin the risk of superimposed PE in women at a high risk of developing this condition due to chronic hypertension and abnormal uterine artery Doppler in the second trimester.

Aspirin group $(n=40)$; placebo group $(n=40)$.

Pravastatin group $(n=11)$ placebo group $(n=10)$.

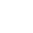
placebo group $(n=50)$. incidence of PE among preg-

To provide daily dietary sup- Supplement group $(n=349)$; Phytonutrient (the contents plements containing antioxi- placebo group $(n=335)$. dants and phytonutrients to pregnant women to reduce

16 studies $(18,907$ participants).
L-arginine $3 \mathrm{~g}$ once daily orally in $600 \mathrm{mg}$ capsules. Beginning at the 20th week of gestation with follow-up every 3 weeks during pregnancy and 2 weeks after birth.

Pravastatin $10 \mathrm{mg}, 1$ capsule There were 4 cases of PE in orally per day until birth. Be- the placebo group and none ginning in the 1 st trimester in the pravastatin group, with (weeks 12 to 16 ) and follow- 5 preterm births before up until birth.

37 weeks in the placebo group compared with 1 in the pravastatin group.

Aspirin $80 \mathrm{mg}, 1$ tablet daily after lunch. Beginning between 12 and 16 weeks of gestation, with no clear follow-up time.

Pills containing $100 \mathrm{mg}$ of aspirin and clear plastic envelopes containing $2 \mathrm{~g}$ of elemental calcium in the form of calcium carbonate. The placebo and powder pills were combined with the study supplements for taste, color, and size. Follow-up since the patient's hospital admission (between weeks 20 to 27 ) up to 6 weeks postpartum.

Main results

Preterm PE occurred in 13 798 participants 1.6\%) in the aspirin group, (4.3\%) participants in the placebo group, a $62 \%$ reduction (adjusted odds ratio [OR] in the aspirin group: $0.38 ; 95 \%$ confidence interval $p=0.004)$

The incidence of severe $\mathrm{PE}$ was higher in the placebo ginine group $(n=$; $p=0.02 ; 95 \% \mathrm{Cl}$ : $0.001-0.031$ )

The aspirin group presented an $\sim 11$-fold reduced risk of developing PE. There was a significant difference between the aspirin and placebo groups in the incidence of PE (2.5\% versus $22.5 \%$ respectively).

The rate of superimposed $\mathrm{PE}$ was $28.6 \%$ lower among women receiving aspirin and calcium than in the placebo group $(52.2 \%$ versus $73.1 \%$ respectively); however, this difference did not reach statistical significance $(p=0.112)$. of the antioxidant supplement capsule consisted of a blend of fruit and vegetable juice powder concentrate). Each capsule contained $7.5 \mathrm{mg}$ of $\beta$-carotene, $234 \mathrm{mg}$ of vitamin C, $30 \mathrm{mg}$ of vitamin E, $420 \mathrm{mg}$ of folate, and $60 \mathrm{mg}$ of calcium. From the $12^{\text {th }}$ week of gestation until birth.

Aspirin alone or in combina- The administration of aspirin tion with dipyridamole with was associated with a reducanother group receiving pla- tion in the risk of developing cebo or no treatment. Gestational age at the start of aspirin use: $<16$ and $>16$ weeks of gestation. Daily dose of the drug: $<100 \mathrm{mg}$ and $\geq 100 \mathrm{mg}$.
No difference was observed in the incidence of PE bethe phytonutrient and placebo groups: $15.9 \%$ versus $16.3 \%$, respectively (relative risk [RR]: 0.97; 95\% Cl: 0.56-1.69). preterm PE (RR: 0.62; 95\%Cl: 0.45-0.87); however, there was no significant effect on term PE (RR: 0.92, 95\% Cl: $0.70-1.21)$. The reduction in preterm PE was confined to the subgroup in which aspirin was initiated before or at 16 weeks gestation, and at a daily dose of $\geq 100 \mathrm{mg}$. There was no significant reduction in the risk of developing 
664 Clinical Procedures for the Prevention of Preeclampsia Moura et al.

Chart 1 (Continued)

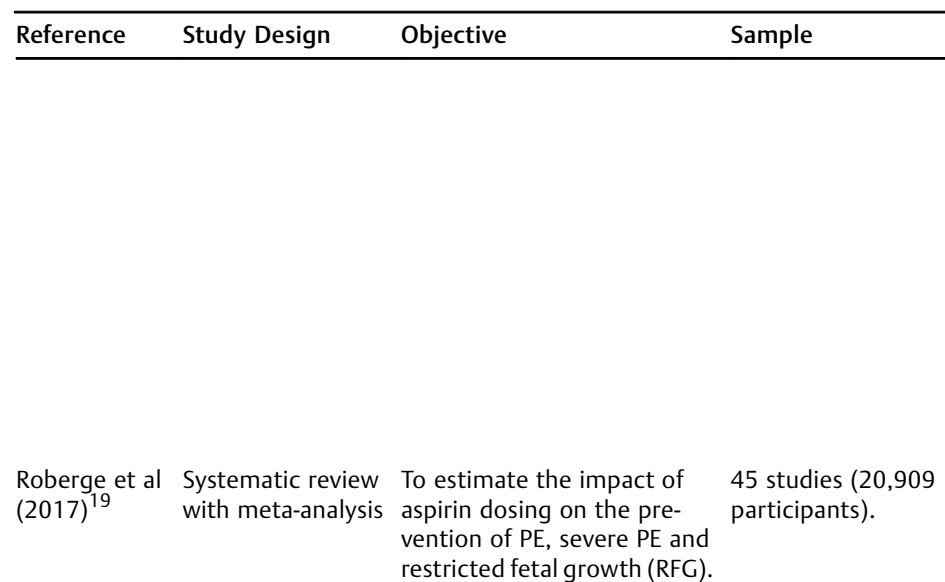

restricted fetal growth (RFG).

Roberge et al Systematic review To estimate the impact of

$(2016)^{20} \quad$ with meta-analysis low-molecular-weight heparin (LMWH) or unfractionated heparin on the low dose of aspirin initiated before or at 16 weeks of gestation in relation to the prevalence of PE and birth of newborns small for gestational age (SGA).

Gan et al Systematic review To comparatively evaluate $(2016)^{21} \quad$ with meta-analysis the efficacy of low-dose aspirin in the prevention of $\mathrm{PE}$ and related fetal complications in East Asian and nonEast Asian pregnant women at risk of developing $\mathrm{PE}$

Rodger et al Systematic review To compare LMWH versus $(2014)^{26} \quad$ with meta-analysis non-LMWH for the prevention of recurrent placentalmediated pregnancy complications.

21 high-quality RCTs were included in the meta-analysis, 3 studies from East Asia, studies.

6 studies (848 participants). and 18 non-East Asian

Aspirin with or without dipyridamole. The dose of aspirin ranged from $50 \mathrm{mg}$ to $150 \mathrm{mg}$ per day, including 2 studies that combined aspirin. The follow-up period response relationship. was not clear.

8 studies (885 participants). Three RCTs used dalteparin, In women with a history of two used enoxaparin, anoth- PE, the addition of LMWH or er two did not specify the unfractionated heparin to a type of $\mathrm{LMWH}$, and one used low dose of aspirin reduced unfractionated heparin. The the risk of developing PE (3 dose of aspirin ranged from RCTs, $n=379$; RR: $0.54 ; 95 \%$ $75 \mathrm{mg}$ to $100 \mathrm{mg} /$ day. The $\mathrm{Cl}: 0.31-0.92 ; p=.03)$, and follow-up period was not $\quad$ SGA ( 2 RCTs, $n=363$; RR: made clear.

0.54 ; $95 \% \mathrm{Cl}: 0.32-0.91$; $p=.02)$.

Aspirin in low doses $(75 \mathrm{mg})$. Low-dose aspirin significantly The follow-up period was not reduced the risk of developmade clear.

ing $P E$ in East Asian $(\mathrm{OR}=0.20 ; 95 \% \mathrm{Cl}$ : $0.11-0.35)$ and non-East Asian women $(\mathrm{OR}=0.84$; 95\% Cl: 0.77-0.92)

LMWH versus non-LMWH. The primary outcome, being The follow-up period was not a composite of $\mathrm{PE}$, birth of a made clear. an SGA newborn (percentile $<10$ ), placental abruption, or termination of pregnancy $>20$ weeks, was significantly reduced by $\mathrm{LMWH}$, with an $\mathrm{RR}$ reduction of 0.52 (95\% Cl: $0.32-0.86$; $p<0.01)$

Low-dose calcium. The fol- The 4 trials with low risk of low-up period was not made bias, all with women at a high clear. risk of developing $\mathrm{PE}$, showed a consistent reduction in $\mathrm{PE}$ (365 women; RR: 0.25; 95\% Cl: 0.12-0.50). However, in three of these trials there was co-intervention with linoleic acid (two trials) or antioxidants. change the estimate. The study ${ }^{13}$ that used calcium for the prevention of PE presented low certainty, even though this drug is already used for this purpose, and is well accepted in populations with calcium deficiency in the diet. This indicates that further studies are likely to have a significant impact on the confidence in the estimate of the effect, and may change the estimate.
Finally, only two studies ${ }^{3,23}$ were classified as very-lowcertainty, suggesting that the estimation of the effect of the administration of pravastatin and heparin as the procedure for the prevention of PE is very uncertain. Perhaps this was due to the fact that these studies had small samples, but statistically significant results, and due to the fact that these procedures are still not used much for this purpose. 
Chart 2 Risk of bias in the studies and classification of the strength of the recommendations

\begin{tabular}{|c|c|c|c|c|c|c|}
\hline \multirow[t]{2}{*}{ Reference } & \multirow[t]{2}{*}{ Outcomes } & \multicolumn{2}{|c|}{$\begin{array}{l}\text { Potential absolute } \\
\text { effects* }(95 \% \mathrm{Cl})\end{array}$} & \multirow{2}{*}{$\begin{array}{l}\text { Relative } \\
\text { effect } \\
-(95 \% \mathrm{Cl})\end{array}$} & \multirow{2}{*}{$\begin{array}{l}\text { Number of } \\
\text { participants } \\
\text { (studies) }\end{array}$} & \multirow{2}{*}{$\begin{array}{l}\text { Certainty in } \\
\text { evidence } \\
\text { (GRADE) }\end{array}$} \\
\hline & & $\begin{array}{l}\text { Comparison } \\
\text { group - risk }\end{array}$ & $\begin{array}{l}\text { Intervention } \\
\text { group - risk }\end{array}$ & & & \\
\hline $\begin{array}{l}\text { Rolnik et al } \\
(2017)^{5}\end{array}$ & $\begin{array}{l}\text { Preterm preeclampsia occurred in } 13 \text { out of the } 798 \\
\text { participants (1.6\%) in the aspirin group, compared } \\
\text { with } 35 \text { out of } 822(4.3 \%) \text { in the placebo group, } \\
\text { when aspirin was started between the } 11 \text { th and } 14 \text { th } \\
\text { gestational weeks and continued until the } 36 \text { th } \\
\text { week. }\end{array}$ & 4 per 100 & $\begin{array}{l}2 \text { per } 100 \\
(1 \text { to } 3)\end{array}$ & $\begin{array}{l}\text { OR: } 0.38 \\
(0.20 \text { to } 0.74)\end{array}$ & $1620(\mathrm{RCT})$ & $\begin{array}{l}\oplus \oplus \oplus \oplus \\
\mathrm{HIGH}\end{array}$ \\
\hline $\begin{array}{l}\text { Camarena } \\
\text { Pulido et al } \\
(2016)^{10}\end{array}$ & $\begin{array}{l}\text { The incidence of severe preeclampsia was greater in } \\
\text { the placebo group }(n=7) \text { than in the L-arginine } \\
\text { group }(n=1 ; p=0.02 ; 95 \% \mathrm{Cl}: 0.001-0.031) \text {. } \\
\text { Follow-up: since } 1 \text { st trimester until birth. }\end{array}$ & 23 per 100 & $\begin{array}{l}0 \text { per } 100 \\
(0 \text { to } 1)\end{array}$ & Not estimable & $96(R C T)$ & $\begin{array}{l}\oplus \oplus \oplus \oplus \\
\mathrm{HIGH}\end{array}$ \\
\hline $\begin{array}{l}\text { Costantine } \\
\text { et al }(2016)^{3}\end{array}$ & $\begin{array}{l}\text { Four subjects in the placebo group developed pre- } \\
\text { eclampsia ( } 3 \text { out of } 4 \text { with severe illness) compared } \\
\text { with none in the pravastatin group. Follow-up: } \\
\text { variation from the } 1 \text { st week to the } 40 \text { th week. }\end{array}$ & 40 per 100 & $\begin{array}{l}0 \text { per } 100 \\
(0 \text { to } 0)\end{array}$ & Not estimable & 21 (RCT) & $\begin{array}{l}\oplus \bigcirc \bigcirc \bigcirc \\
\text { VERY LOW }\end{array}$ \\
\hline $\begin{array}{l}\text { Talari et al } \\
(2014)^{9}\end{array}$ & $\begin{array}{l}\text { There was a significant difference between the } \\
\text { aspirin and placebo groups in the incidence of } \\
\text { preeclampsia ( } 2.5 \% \text { versus } 22.5 \% \text { respectively). The } \\
\text { aspirin group presented an } \sim 11 \text {-fold reduced risk of } \\
\text { developing preeclampsia. }\end{array}$ & 25 per 100 & $\begin{array}{l}79 \text { per } 100 \\
\text { (31 to } 97)\end{array}$ & $\begin{array}{l}\text { OR: } 11.323 \\
(1.360 \text { to } 94.248)\end{array}$ & $80(\mathrm{RCT})$ & $\begin{array}{l}\oplus \oplus \oplus \oplus \\
\mathrm{HIGH}\end{array}$ \\
\hline $\begin{array}{l}\text { Souza et al } \\
(2014)^{14}\end{array}$ & $\begin{array}{l}\text { The rate of superimposed preeclampsia was } 28.6 \% \\
\text { lower among women receiving aspirin and calcium } \\
\text { when compared to the placebo group ( } 52.2 \text { versus } \\
73.1 \% \text { respectively); however, this difference did not } \\
\text { reach statistical significance }(p=.112 \text { ). Follow-up: } \\
\text { variation from hospital admission to birth. }\end{array}$ & 73 per 100 & $\begin{array}{l}0 \text { per } 100 \\
(0 \text { to } 0)\end{array}$ & Not estimable & 49 (RCT) & $\begin{array}{l}\oplus \oplus \oplus \oplus \\
\mathrm{HIGH}\end{array}$ \\
\hline $\begin{array}{l}\text { Parrish et al } \\
(2013)^{27}\end{array}$ & $\begin{array}{l}\text { No difference was observed in the incidence of } \\
\text { preeclampsia between the phytonutrient and pla- } \\
\text { cebo groups ( } 15.9 \% \text { versus } 16.3 \% \text { respectively). } \\
\text { Follow-up: variation from the } 12 \text { th week to birth. }\end{array}$ & 33 per 100 & $\begin{array}{l}32 \text { per } 100 \\
(18 \text { to } 55)\end{array}$ & $\begin{array}{l}\text { OR: } 0.97 \\
(0.56 \text { to } 1.69)\end{array}$ & 267 (RCT) & $\begin{array}{l}\oplus \oplus \oplus \oplus \\
\mathrm{HIGH}\end{array}$ \\
\hline $\begin{array}{l}\text { Roberge et al } \\
(2018)^{25}\end{array}$ & $\begin{array}{l}\text { The administration of aspirin was associated with a } \\
\text { reduction in the risk of developing preterm pre- } \\
\text { eclampsia (RR: } 0.62 ; 95 \% \mathrm{Cl}: 0.45-0.87 \text { ); however, } \\
\text { there was no significant effect on term preeclampsia } \\
\text { (RR: } 0.92 ; 95 \% \mathrm{Cl}: 0.70-1.21 \text { ). }\end{array}$ & 0 per 100 & $\begin{array}{l}0 \text { per } 100 \\
(0 \text { to } 0)\end{array}$ & $\begin{array}{l}\text { OR: } 0.62 \\
(0.45 \text { to } 0.87)\end{array}$ & (16 RCTs) & $\oplus \oplus \oplus \oplus \mathrm{HIGH}$ \\
\hline $\begin{array}{l}\text { Roberge et al } \\
(2017)^{19}\end{array}$ & $\begin{array}{l}\text { Aspirin was associated with a significant reduction in } \\
\text { the prevalence of preeclampsia, severe preeclamp- } \\
\text { sia and fetal growth restriction, with a significant } \\
\text { dose-response relationship when initiated before } \\
\text { the 16th week of gestation. }\end{array}$ & 0 per 100 & $\begin{array}{l}0 \text { per } 100 \\
(0 \text { to } 0)\end{array}$ & $\begin{array}{l}\text { OR: } 0.57 \\
(0.43 \text { to } 0.75)\end{array}$ & (45 RCTs) & $\oplus \oplus \oplus \oplus \mathrm{HIGH}$ \\
\hline $\begin{array}{l}\text { Roberge et al } \\
(2016)^{20}\end{array}$ & $\begin{array}{l}\text { The addition of low-molecular-weight heparin or } \\
\text { unfractionated heparin to low dose aspirin reduced } \\
\text { the risk of developing preeclampsia. }\end{array}$ & 0 per 100 & $\begin{array}{l}0 \text { per } 100 \\
(0 \text { to } 0)\end{array}$ & $\begin{array}{l}\text { OR: } 0.54 \\
(0.31 \text { to } 0.92)\end{array}$ & (8 RCTs) & $\begin{array}{l}\oplus \oplus \oplus \bigcirc \\
\text { MODERATE }^{\mathrm{C}}\end{array}$ \\
\hline $\begin{array}{l}\text { Gan et al } \\
(2016)^{21}\end{array}$ & $\begin{array}{l}\text { The low dose of aspirin }(75 \mathrm{mg}) \text { significantly reduced } \\
\text { the risk of developing preeclampsia in East Asian and } \\
\text { non-East Asian women. }\end{array}$ & 0 per 100 & $\begin{array}{l}0 \text { per } 100 \\
(0 \text { to } 0)\end{array}$ & $\begin{array}{l}\text { OR: } 0.20 \\
(0.11 \text { to } 0.35)\end{array}$ & (21 RCTs) & $\begin{array}{l}\oplus \oplus \oplus \bigcirc \\
\text { MODERATE }\end{array}$ \\
\hline $\begin{array}{l}\text { Rodger et al } \\
(2014)^{26}\end{array}$ & $\begin{array}{l}\text { The primary outcome, being a composite of pre- } \\
\text { eclampsia, birth of a newborn small for gestational } \\
\text { age (percentile }<10) \text {, placental abruption, or ter- } \\
\text { mination of pregnancy }>20 \text { weeks, were signifi- } \\
\text { cantly reduced by low-molecular-weight heparin, } \\
\text { with an RR reduction of } 0.52 \text { (95\%Cl: } 0.32-0.86 \text {; } p \\
<.01)\end{array}$ & 0 per 100 & $\begin{array}{l}0 \text { per } 100 \\
(0 \text { to } 0)\end{array}$ & $\begin{array}{l}\text { OR: } 0.52 \\
(0.32 \text { to } 0.86)\end{array}$ & (6 RCTs) & $\begin{array}{l}\oplus \bigcirc \bigcirc \bigcirc \\
\text { VERY LOW }\end{array}$ \\
\hline $\begin{array}{l}\text { Hofmeyr et al } \\
(2014)^{13}\end{array}$ & $\begin{array}{l}\text { The four trials with low risk of bias, all in women at a } \\
\text { high risk of developing preeclampsia, showed a } \\
\text { consistent reduction in the incidence of pre- } \\
\text { eclampsia, even with calcium started at the end of } \\
\text { the pregnancy. }\end{array}$ & 0 per 100 & $\begin{array}{l}0 \text { per } 100 \\
(0 \text { to } 0)\end{array}$ & $\begin{array}{l}\text { RR: } 0.38 \\
(0.28 \text { to } 0.52)\end{array}$ & (9 RCTs) & $\oplus \oplus \bigcirc \bigcirc$ Low \\
\hline
\end{tabular}

Abbreviations: $95 \% \mathrm{Cl}$, 95\% confidence interval; GRADE, Gradings of Recommendations, Assessment, Development and Evaluations; OR, odds ratio; $R C T$, randomized controlled trial; RR, risk ratio.

Notes: ${ }^{*}$ The risk in the intervention group (and its $95 \%$ confidence interval) is based on the risk assumed for the comparison group and the relative effect of the intervention (and its $95 \%$ confidence interval).

anaccurate due to not presenting confidence interval.

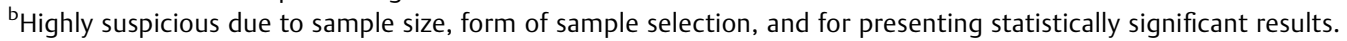

'Due to the heterogeneity of the selected studies. 


\section{Discussion}

The present review included 12 studies that addressed different procedures for the prevention of PE, and they were published in the previous 5 years. Most studies used the administration of aspirin as the procedure to prevent PE. Three of them used only aspirin ${ }^{5,9,21}$, and another four ${ }^{14,19,20,25}$ used aspirin combined with calcium, heparin or dipyridamole. These findings are in line with the international recommendations for women at a high risk of developing PE. ${ }^{17,18}$

In all of the studies, the expected outcome, the prevention of PE, was achieved. This fact confirms the efficacy of aspirin when administered to pregnant women at a high risk of developing PE when it is started prior to the 16th week of pregnancy, preferably between weeks 11 and 14. Regarding the ideal dose, the studies have administered doses between $50 \mathrm{mg}$ and $150 \mathrm{mg}$, and most suggest that the dose should be higher than $100 \mathrm{mg}$ in order to achieve satisfactory effects. $5,9,14,19-21$

The recommendation for the use of aspirin is associated with uteroplacental underperfusion due to impaired placentation, placental vascular lesions, and incomplete transformation of the spiral uterine arteries. ${ }^{14}$ Approximately 30 thousand women have already participated in RCTs with aspirin, thus making this one of the most intensely studied drugs in obstetrics. ${ }^{22}$ Physiologically, reduced placental blood flow is thought to lead to the activation of the coagulation cascade, platelet aggregation and endothelial dysfunction, which may be partially mediated by prostacyclin and thromboxane A2, so that aspirin selectively reduces thromboxane A2 without significantly affecting prostacyclin levels and also inhibiting placental aggregation. $^{21}$

The low dose of aspirin inhibits the biosynthesis of platelet thromboxane $A 2$ by altering the imbalance between thromboxane A2 and prostacyclin, and is therefore thought to favor vasodilation, which assists in the reduction of blood pressure and the prevention of $\mathrm{PE}{ }^{23}$ This mechanism has achieved good results in practice, more in reducing the incidence of PE in high-risk women than in those of low and moderate risk. ${ }^{14}$

It is recommended that antiplatelet agents be administered to pregnant women at a high risk of developing PE or to those with chronic hypertension, as they lead to a wide reduction in adverse pregnancy outcomes for both the mother and the newborn. ${ }^{24}$ The results of the systematic reviews showed that antiplatelet agents are associated with a reduction in the risk of developing preterm PE (relative risk [RR]: 0.62; 95\%CI: 0.45-0.87), when initiated before the 16th gestational week, and they are also associated with a significant reduction in the prevalence of $\mathrm{PE}$, severe $\mathrm{PE}$, and restricted intrauterine growth. ${ }^{19,25}$

For LMWH, a meta-analysis showed that heparin alone reduced the risk of: severe or early onset of PE (1.7\% versus 13.4\%; RR: 0.16 ; 95\%CI: 0.07-0.36), preterm birth (< 37 weeks; $32.1 \%$ versus $47.7 \%$; RR: 0.77; 95\%CI: 0.62-0.96) and SGA newborns (10.1\% versus $29.4 \%$; RR: 0.42 ; $95 \% \mathrm{CI}$ :
0.29-0.59), without a significant effect on gestational termination (> 20 weeks) (1.9\% versus 5.3\%; RR: 0.41 ; $95 \%$ CI: 0.17-1.02). ${ }^{26}$

The second most frequent procedure in the selected studies was the prescription of calcium, although administered alone it obtained low certainty. ${ }^{13}$ In the other studies $^{14,27}$, calcium was combined with other medications, such as phytonutrients and aspirin, both of which obtained high certainty.

Calcium is also used for the prevention of PE because there is epidemiological, clinical and laboratory evidence that indicates the association of dietary calcium deficiency with hypertensive disorders of pregnancy. ${ }^{13}$ Like aspirin, calcium is recommended by international societies, and the doses range from $1.5 \mathrm{~g}$ to $2.0 \mathrm{~g}$ of elemental calcium daily for pregnant women residing in areas with low dietary intake of calcium. ${ }^{17,18}$

One systematic review ${ }^{28}$ highlighted calcium supplementation ( $1 \mathrm{~g}$ to $2 \mathrm{~g} /$ day) for the prevention of PE, and found that calcium supplementation significantly reduces the risk (between 55\% and 64\%) in women with low dietary calcium intake. In addition, calcium supplements have a significant protective effect on maternal mortality and severe morbidity and premature delivery, with a tendency to reduce the risks of low birth weight and stillbirth. ${ }^{24}$

Another procedure found in one study ${ }^{27}$ was the use of phytonutrients for the prevention of PE. The contents of the antioxidant supplement capsule consisted of a blend of fruits and vegetable juice powder concentrate derived from acerola, cherry, apple, beetroot, broccoli, cabbage, carrot, blackberry, kale, orange, peach, papaya, parsley, pineapple, spinach and tomato, with each capsule providing $7.5 \mathrm{mg}$ of $\beta$-carotene, $234 \mathrm{mg}$ of vitamin C, $30 \mathrm{mg}$ of vitamin $\mathrm{E}$ in the form of RRR- $\alpha$ tocopherol, $420 \mathrm{mg}$ of folate, and $60 \mathrm{mg}$ of calcium. It was initiated in the 12th week of gestation, and the use was maintained until birth. ${ }^{27}$ This study, ${ }^{27}$ even with high certainty, found no difference between the phytonutrient and placebo groups in the prevention of $\mathrm{PE}$, discouraging its use in the clinical practice.

In relation to the administration of pravastatin and Larginine, both are innovative procedures that are little used in the prevention of PE. However, their real benefits are still unclear, as studies are still incipient. In the present review, the studies $^{3,10}$ regarding their administration were classified as very-low-certainty and high-certainty respectively. Pravastatin $(10 \mathrm{mg})$ is a hydrophilic statin used to lower serum cholesterol and prevent cardiovascular disease. Some of the main characteristics of PE are angiogenic imbalance, exaggerated inflammation, and endothelial dysfunction, which lead to clinical manifestations of hypertension, proteinuria and target-organ damage. Furthermore, although PE is a disease exclusive to pregnancy, it has pathogenic similarities and is associated with many risk factors for cardiovascular disease in adults. $^{3}$

The use of statins in the treatment of PE has taken a leading role in recent years. In particular that of pravastatin, with many studies and strong scientific evidence supporting its use as the statin of first therapeutic option for the treatment of early and 
severe forms, which is in disagreement with the findings of the present review. ${ }^{29}$ The ability of statins to reverse the angiogenic imbalance that is characteristic of PE, and to restore endothelial dysfunction in animal models, demonstrates the need for clinical trials that further assess the efficacy of pravastatin. ${ }^{29,30}$

Unlike pravastatin, L-arginine ( $3 \mathrm{~g}$ ) was classified as highcertainty. L-arginine is a basic amino acid nitric oxide precursor that has the ability to dilate vessels and improve blood flow and circulation. ${ }^{10}$

In a study ${ }^{10}$ included in the present review, the number of pregnant women with severe PE was higher in the placebo group; in addition, the systolic blood pressure, the diastolic blood pressure and the mean arterial pressure were significantly lower in the L-arginine group compared with the placebo group. This demonstrates that the oral treatment with $3 \mathrm{~g}$ per day of L-arginine has a significant effect on the prevention of PE in high-risk patients, as well as on the ability to avoid more severe outcomes.

The cost of L-arginine is high compared with that of aspirin; however, the benefits of L-arginine in the prevention of PE exceed the cost of treating PE. Furthermore, Larginine showed good results when administered to patients with 19 to 20 weeks of gestation. L-arginine therapy may be important because many patients with PE have their first consultation with a physician when it is too late for other treatments, such as the one with aspirin, to be effective.

Although there was no limit to the type of conduct for the prevention of PE, to obtain more publications on the subject, none of the studies verified the relationship between nonmedicated treatment and the prevention of PE. Moreover, we found no studies that evaluated women classified as low risk for PE, and the conduct for this population.

\section{Conclusion}

Based on the studies included in the present review, the administration of aspirin is considered the best procedure for the prevention of PE in high-risk women, which corroborates the results of several studies published in recent years. Further studies are needed to identify and test other medications and their benefits during pregnancy in the prevention of adverse maternal and perinatal outcomes.

\section{Conflict of Interests}

The authors have no conflict of interesst to declare.

\section{Acknowledgments}

We would like to thank Conselho Nacional de Desenvolvimento Científico e Tecnológico (CNPq), which contributed with grant (PQ-1D) n 306078/2019-8, Coordenação de Aperfeiçoamento de Pessoal de Nível Superior (CAPES), and Fundação Cearense de Apoio ao Desenvolvimento Científico e Tecnológico (FUNCAP), which contributed with the fellowships.

\section{References}

1 Torjusen H, Brantsæter AL, Haugen M, Alexander J, Bakketeig LS, Lieblein $G$, et al. Reduced risk of pre-eclampsia with organic vegetable consumption: results from the prospective Norwegian Mother and Child Cohort Study. BMJ Open. 2014;4(09):e006143. Doi: 10.1136/bmjopen-2014-006143

2 Lee SM, Moon JY, Lim BY, Kim SM, Park CW, Kim BJ, et al. Increased biosynthesis and accumulation of cholesterol in maternal plasma, but not amniotic fluid in pre-eclampsia. Sci Rep. 2019;9(01): 1550. Doi: 10.1038/s41598-018-37757-3

3 Costantine MM, Cleary K, Hebert MF, Ahmed MS, Brown LM, Ren $Z$, et al; Eunice Kennedy Shriver National Institute of Child Health and Human Development Obstetric-Fetal Pharmacology Research Units Network. Safety and pharmacokinetics of pravastatin used for the prevention of preeclampsia in high-risk pregnant women: a pilot randomized controlled trial. Am J Obstet Gynecol. 2016;214(06):720.e1-720.e17. Doi: 10.1016/j. ajog.2015.12.038

4 Say L, Chou D, Gemmill A, Tunçalp O, Moller AB, Daniels J, et al. Global causes of maternal death: a WHO systematic analysis. Lancet Glob Health. 2014;2(06):e323-e333. Doi: 10.1016/S2214109X(14)70227-X

5 Rolnik DL, Wright D, Poon LC, O'Gorman N, Syngelaki A, Matallana $\mathrm{CP}$, et al. Aspirin versus placebo in pregnancies at high risk for preterm preeclampsia. N Engl J Med. 2017;377(07):613-622. Doi: 10.1056/NEJMoa1704559

6 Erez O, Romero R, Maymon E, Chaemsaithong P, Done B, Pacora P, et al. The prediction of late-onset preeclampsia: Results from a longitudinal proteomics study. PLoS One. 2017;12(07):e0181468. Doi: 10.1371/journal.pone.0181468

7 Guida JPS, Surita FG, Parpinelli MA, Costa ML. Preterm preeclampsia and timing of delivery: a systematic literature review. Rev Bras Ginecol Obstet. 2017;39(11):622-631. Doi: 10.1055/s-0037-1604103

8 Stevens W, Shih T, Incerti D, Ton TGN, Lee HC, Peneva D, et al. Short-term costs of preeclampsia to the United States health care system. Am J Obstet Gynecol. 2017;217(03):237-248.e16. Doi: 10.1016/j.ajog.2017.04.032

9 Talari H, Mesdaghinia E, Abedzadeh Kalahroudi M. Aspirin and preeclampsia prevention in patients with abnormal uterine artery blood flow. Iran Red Crescent Med J. 2014;16(08):e17175. Doi: 10.5812/ircmj. 17175

10 Camarena Pulido EE, García Benavides L, Panduro Barón JG, Pascoe Gonzalez S, Madrigal Saray AJ, García Padilla FE, et al. Efficacy of Larginine for preventing preeclampsia in high-risk pregnancies: A double-blind, randomized, clinical trial. Hypertens Pregnancy. 2016;35(02):217-225. Doi: 10.3109/10641955.2015.1137586

11 Rocha RS, Alves JAG, Maia E Holanda Moura SB, Araujo Júnior E, Peixoto AB, Santana EFM, et al. Simple approach based on maternal characteristics and mean arterial pressure for the prediction of preeclampsia in the first trimester of pregnancy. J Perinat Med. 2017;45(07):843-849. Doi: 10.1515/jpm-2016-0418

12 O'Gorman N, Wright D, Syngelaki A, Akolekar R, Wright A, Poon LC, et al. Competing risks model in screening for preeclampsia by maternal factors and biomarkers at 11-13 weeks gestation. Am J Obstet Gynecol. 2016;214(01):103.e1-103.e12. Doi: 10.1016/j. ajog.2015.08.034

13 Hofmeyr GJ, Belizán JM, von Dadelszen P; Calcium and Preeclampsia (CAP) Study Group. Low-dose calcium supplementation for preventing pre-eclampsia: a systematic review and commentary. BJOG. 2014;121(08):951-957. Doi: 10.1111/14710528.12613

14 Souza EV, Torloni MR, Atallah AN, Santos GMS, Kulay L Jr, Sass N. Aspirin plus calcium supplementation to prevent superimposed preeclampsia: a randomized trial. Braz J Med Biol Res. 2014;47 (05):419-425. Doi: 10.1590/1414-431X20143629

15 Moher D, Liberati A, Tetzlaff J, Altman DG; PRISMA Group. Preferred reporting items for systematic reviews and meta- 
analyses: the PRISMA statement. PLoS Med. 2009;6(07): e1000097. Doi: 10.1371/journal.pmed.1000097

16 Schünemann H, Brożek J, Guyatt G, Oxman A. Handbook for grading quality of evidence and strength of recommendations using the GRADE approach [Internet]. 2013 [cited 2018 Dec 10]. Available from: https://gdt.gradepro.org/app/handbook/handbook.html

17 World Health Organization. WHO recommendations for prevention and treatment of preeclampsia and eclampsia [Internet]. Geneva: WHO; 2011 [cited 2018 Dec 10]. Available from: https:// apps.who.int/iris/bitstream/handle/10665/44703/ 9789241548335_eng.pdf?sequence $=1$

18 ACOG Practice Bulletin No. 203: chronic hypertension in pregnancy. Obstet Gynecol. 2019;133(01):e26-e50. Doi: 10.1097/ AOG.0000000000003020

19 Roberge S, Nicolaides K, Demers S, Hyett J, Chaillet N, Bujold E. The role of aspirin dose on the prevention of preeclampsia and fetal growth restriction: systematic review and meta-analysis. Am J Obstet Gynecol. 2017;216(02):110-120.e6. Doi: 10.1016/j.ajog.2016.09.076

20 Roberge S, Demers S, Nicolaides KH, Bureau M, Côté S, Bujold E. Prevention of pre-eclampsia by low-molecular-weight heparin in addition to aspirin: a meta-analysis. Ultrasound Obstet Gynecol. 2016;47(05):548-553. Doi: 10.1002/uog.15789

21 Gan J, He H, Qi H. Preventing preeclampsia and its fetal complications with low-dose aspirin in East Asians and non-East Asians: A systematic review and meta-analysis. Hypertens Pregnancy. 2016;35(03):426-435. Doi: 10.1080/10641955.2016.1178772

22 Tong S, Mol BW, Walker SP. Preventing preeclampsia with aspirin: does dose or timing matter? Am J Obstet Gynecol. 2017;216(02): 95-97. Doi: 10.1016/j.ajog.2016.12.003

23 Panagodage S, Yong HEJ, Da Silva Costa F, Borg AJ, Kalionis B, Brennecke SP, et al. Low-dose acetylsalicylic acid treatment modulates the production of cytokines and improves trophoblast function in an in vitro model of early-onset preeclampsia. Am J Pathol. 2016;186(12):3217-3224. Doi: 10.1016/j.ajpath. 2016.08.010

24 von Dadelszen P, Magee LA. Preventing deaths due to the hypertensive disorders of pregnancy. Best Pract Res Clin Obstet Gynaecol. 2016;36:83-102. Doi: 10.1016/j.bpobgyn.2016.05.005

25 Roberge S, Bujold E, Nicolaides KH. Aspirin for the prevention of preterm and term preeclampsia: systematic review and metaanalysis. Am J Obstet Gynecol. 2018;218(03):287-293.e1. Doi: 10.1016/j.ajog.2017.11.561

26 Rodger MA, Carrier M, Le Gal G, Martinelli I, Perna A, Rey E, et al; Low-Molecular-Weight Heparin for Placenta-Mediated Pregnancy Complications Study Group. Meta-analysis of low-molecularweight heparin to prevent recurrent placenta-mediated pregnancy complications. Blood. 2014;123(06):822-828. Doi: 10.1182/blood2013-01-478958

27 Parrish MR, Martin JN Jr, Lamarca BB, Ellis B, Parrish SA, Owens MY, et al. Randomized, placebo controlled, double blind trial evaluating early pregnancy phytonutrient supplementation in the prevention of preeclampsia. J Perinatol. 2013;33(08):593-599. Doi: 10.1038/ jp.2013.18

28 Lassi ZS, Mansoor T, Salam RA, Das JK, Bhutta ZA. Essential prepregnancy and pregnancy interventions for improved maternal, newborn and child health. Reprod Health. 2014;11(Suppl 1):S2. Doi: 10.1186/1742-4755-11-S1-S2

29 Esteve-Valverde E, Ferrer-Oliveras R, Gil-Aliberas N, BaraldèsFarré A, Llurba E, Alijotas-Reig J. Pravastatin for preventing and treating preeclampsia: a systematic review. Obstet Gynecol Surv. 2018;73(01):40-55. Doi: 10.1097/OGX.0000000000000522

30 Costantine MM, Ananth CV. The early developments of preeclampsia drugs. Expert Opin Investig Drugs. 2016;25(08): 867-870. Doi: 10.1080/13543784.2016.1196185 